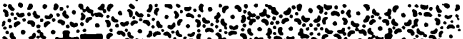 \\ (u) \\ 血中 PCB パターンが BC タイプを示す症例についての考察
}

(昭和 63 年 4 月 4 日受理)

$\begin{array}{lll}\text { 中川礼子*1 } & \text { 飯田隆雄*1 } & \text { 竹 中重 幸*1 } \\ \text { 深町和 美*1 } & \text { 高橋克 } \text { 巳 }^{* 1} \text { 旭 正 一*2 }\end{array}$

\section{Characterization of Subjects with Type BC Pattern of Blood PCB on Gas Chromatography}

\author{
Reiko NaKagawa ${ }^{* 1}$, Takao IIdA*1, Shigeyuki TakenakA*1, Kazumi FukamaChi*1, \\ Katsumi TAKAHASHI ${ }^{* 1}$ and Masakazu AsAHI ${ }^{* 2}$ \\ (*1Fukuoka Environmental Research Center: Mukaisano, Dazaifu-shi, Fukuoka, Japan; \\ *2 Department of Dermatology, University of Occupational and Environmental \\ Health: 1-1, Iseigaoka, Yahata nishi-ku, kitakyushu-shi, Japan).
}

To characterize subjects whose blood $\mathrm{PCB}$ patterns were of Type $\mathrm{BC}$ on gas chromatography, we determined polychlorinated biphenyls (PCBs) and polychlorinated quaterphenyls (PCQs) in the blood and adipose tissue. On the basis of PCQ concentration in the blood, the subjects were divided into 3 groups: high level $(>1.000 \mathrm{ppb})$, intermediate level $(0.044 \sim 1.000$ $\mathrm{ppb})$ and low level $(<0.044 \mathrm{ppb})$.

Furthermore polychlorinated dibenzofurans $\left(2,3,7,8-\mathrm{T}_{4} \mathrm{CDF}, 2,3,4,7,8-\mathrm{P}_{5} \mathrm{CDF}\right.$ and $1,2,3,4,7$, $8-\mathrm{H}_{6} \mathrm{CDF}$ ) were determined with the adipose tissue of the intermediate PCQ level subjects. From these results it was strongly suggested that the group of intermediate PCQ level subjects could be subdivided into two categories: those who had apparently taken Yusho-causing oil and those who are supposed not to have taken it.

(Received April 4, 1988)

Key words: $\mathrm{PCB}$ パターン $\mathrm{PCB}$ pattern; ポリ塩化クアテルフェニル polychlorinated quaterphenyl (PCQ); ポリ塩化ジベンゾフラン polychlorinated dibenzofuran (PCDF); 油症 Yusho

\section{緒 言}

人の血中 PCB のガスクロマトグラムピークパターン は基本的に $\mathrm{A}, \mathrm{B} 及 ひ ゙ \mathrm{C}$ のイプに分別されることが増 田らによって報告された ${ }^{1)}$.すなわち，彼らは自覚症状及 び他覚所見から明らかに油症であると認定された人（油 症患者）が健常者と異なる血中 PCB ガスクロマトグラ ムを示すことを明らかにした，そして，その中でも特徵 的な PCB ガスクロマトグラムを示すむのを A タイプと

*1 福岡県衛生公害センター：福岡県太宰府市大字向佐野字 迎田

*2 産業医科大学皮鬳科学教室：北九州市八幡西区医生ヶ丘 $1-1$
した. また通常の健常者と同じ PCBクロマトグラムを 示すものを $\mathrm{C}$ タイプとし, 自覚症状及び他覚所見からも 明らかに油症と認定され, かつ $\mathrm{A}$ タイプと C タイプの 中間型 PCB クロマトグラムを示すものを B タイプとし た.

近年，上記のタイプに加えて他覚所見では油症と診断 することが困難で， かつ血中 PCB ガスクロマトグラム パターンでは $\mathrm{B}$ タイプと C タイプの中間型を示すタイ プが現れ，このタイプを $\mathrm{BC}$ としてい. 従って現在で は $\mathrm{PCB}$ パターンに $\mathrm{A}, \mathrm{B}, \mathrm{BC}$ 及び C の 4 タイプが存在 していることになる.これらのパターンは長期間の観察 による亡, 相互間の移行変化は極めて少なく, ある程度 
Table 1. GC/MS Conditions

\begin{tabular}{lll}
\hline Mass spectrometer $:$ & Vg $70-\mathrm{s}$ \\
Gas chromatograph: & Hewlett-Packard $5890 \mathrm{~A}$ \\
Column & $:$ & SP 2331 cross-rinked fused silica capillary column \\
& & $30 \mathrm{~m} \times 0.25 \mathrm{~mm} \mathrm{i.d.,} 0.20 \mu \mathrm{m}$ \\
Column temp. $\quad:$ & $120^{\circ} \mathrm{C}(2 \mathrm{~min}) \sim 220^{\circ} \mathrm{C}, 15^{\circ} \mathrm{C} / \mathrm{min}$ \\
& & $220^{\circ} \mathrm{C}(15 \mathrm{~min}) \sim 240^{\circ} \mathrm{C}, 20^{\circ} \mathrm{C} / \mathrm{min}$ \\
Injector temp. $\quad:$ & $270^{\circ} \mathrm{C}$ \\
\hline
\end{tabular}

Table 2. The PCBs and PCQs Concentration in the Blood and Adipose Tissue of Yusho Patients, NonYusho Dermal Patients (Other Patients) and Normal Persons

\begin{tabular}{|c|c|c|c|c|c|c|}
\hline \multirow{2}{*}{\multicolumn{2}{|c|}{ Subjects }} & \multirow[b]{2}{*}{ No. } & \multicolumn{2}{|c|}{ Blood } & \multicolumn{2}{|c|}{ Adipose tissue } \\
\hline & & & $\begin{array}{l}\text { PCBs (ppb) } \\
\text { Mean } \pm \text { S. D. } \\
\text { (Min Max) }\end{array}$ & $\begin{array}{l}\text { PCQs (ppb) } \\
\text { Mean } \pm \text { S. D. } \\
\text { (Min } \sim \text { Max) }\end{array}$ & $\begin{array}{l}\text { PCBs (ppb) } \\
\text { Mean } \pm \text { S. D. } \\
(\text { Min } \sim \text { Max) }\end{array}$ & $\begin{array}{l}\text { PCQs (ppb) } \\
\text { Mean } \pm \text { S. D. } \\
\text { (Min } \sim \text { Max) }\end{array}$ \\
\hline \multirow[t]{3}{*}{ Yusho patients } & Type A & 7 & $\begin{array}{c}9.65 \pm 6.34 \\
(2.03 \sim 20.60)\end{array}$ & $\begin{array}{c}6.97 \pm 3.38 \\
(3.86 \sim 13.89)\end{array}$ & $\begin{array}{c}2,150 \pm 1,660 \\
(1,000 \sim 5,710)\end{array}$ & $\begin{array}{r}1,060.00 \pm 469.00 \\
(555 \sim 1,997)\end{array}$ \\
\hline & Type BC & 3 & $\begin{array}{c}3.06 \pm 1.72 \\
(1.67 \sim 5.48)\end{array}$ & $\begin{array}{c}0.075 \pm 0.067 \\
(0.010 \sim 0.168)\end{array}$ & $\begin{array}{r}1,183 \pm 268 \\
(820 \sim 1,460)\end{array}$ & $\begin{array}{r}23.08 \pm 24.11 \\
(1.38 \sim 56.70)\end{array}$ \\
\hline & Type C & 8 & $\begin{array}{c}5.53 \pm 2.28 \\
(2.22 \sim 8.80)\end{array}$ & $\begin{array}{c}0.023 \pm 0.010 \\
(0.010 \sim 0.041)\end{array}$ & $\begin{array}{c}1,191 \pm 376 \\
(580 \sim 1,750)\end{array}$ & $\begin{aligned} 5.38 \pm & 2.14 \\
(1.38 \sim & 8.22)\end{aligned}$ \\
\hline Other patients & & 20 & $\begin{array}{c}3.15 \pm 2.63 \\
(1.00 \sim 12.00)\end{array}$ & $\begin{array}{c}0.051 \pm 0.137 \\
(0.001 \sim 0.638)\end{array}$ & $\begin{array}{l}786 \pm \quad 457 \\
(178 \sim 2,217)\end{array}$ & $\begin{array}{l}10.69 \pm 25.88 \\
(0.03 \sim 120.29)\end{array}$ \\
\hline Normal persons & & 11 & $\begin{array}{c}3.84 \pm 1.32 \\
(1.29 \sim 5.95)\end{array}$ & $\begin{array}{c}0.021 \pm 0.012 \\
(0.010 \sim 0.051)\end{array}$ & $\begin{array}{c}893 \pm 262 \\
(440 \sim 1,250)\end{array}$ & $\begin{array}{cc}4.15 & 3.82 \\
(1.65 \sim & 15.20)\end{array}$ \\
\hline
\end{tabular}

の恒常性があると報告されている2!． 従ってこのことが このパターンが油症診断基準*1に採用されてきた所似で あある。,一方，著者らは既に，これらのパターンと皮下 脂肪中ポリ塩化クアテルフェニール $(\mathrm{PCQ})$ の量に高い 相関を指摘し, 両者に極めて直接の関係があることを明 らかにした³. 今回油症患者 18 名, 油症患者ではない皮 膚疾患患者 (非油症患者) 20 名及び健常者 11 名の計 49 名の血液と皮下脂肪中の PCB 及び PCQ について分析 した結果, 非油症患者の中に血中 $\mathrm{PCB}$ パターンが $\mathrm{BC}$ タイプで, 血液と皮下脂肪に油症患者に近い高濃度の $\mathrm{PCQ}$ を有する症例を発見した. $\mathrm{PCB}$ パターンの $\mathrm{BC}$ 夕 イプについては，これについての臨床的報告例がなく， A 及び B タイプに比べるとその中毒学的意義が明確で ない.しかしながら，BC タイプのような境界領域の症例 群は, 閾値などを含む油症の発症機作を明らかにする上 では, 重要な意味を持つ症例群であると考えられる。 そ こで，この BC タイプの症例群について，PCQ 濃度を尺 度とし, 他の症例群と比較検討した. 又, ポリ塩化ジべ ンゾフラン (PCDFs) についても測定したので報告する.

*1 昭和 52 年 6 月 14 日改訂の油症診断基準に重要な所見之 して, ざ瘡様皮疹, 色素沈着と並び, 血液 PCB の性状及び 濃度の異常が列記されている.

\section{対象と方法}

1. 対

分析対象は油症患者 18 名 (A タイプ7名, BC タイプ 3 名, C タイプ 8 名), 健常者 11 名, 及び九州大学医学 部皮膚科学教室において採取された油症でない皮膚科外 来患者 20 名の合計 49 名の血液と皮下脂肪である。 い ずれも昭和 61 年に採取されたものである，血液は上腕 部时静脈からへパリン入真空採血管により採取し，分析 に供するまで冷蔵庫中に $4^{\circ}$ で保存した。皮下脂肪は被 検者の腹部皮膚を切開して採取し，分析に供するまで冷 蔵庫中に $-20^{\circ}$ で保存した。

\section{2. 試薬}

PCB, PCQ 及び PCDF 分析に用いた試薬は，キシダ化 学(株)製残農 PCB 分析用トルェン, 半井化学薬品(株) 製カラムクロマトグラフィー用活性炭, 和光純薬工業 (株)製 $n$-デカン，その他は別報了!4) と同じあのを用いた。

\section{3. 分析方法, 分析装置及び測定条件}

PCB, PCQ 分析は別報 ${ }^{31,4)}$ と同様に行った.

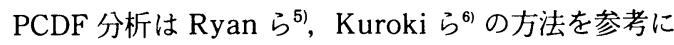
しながら以下のとおり行った。

試料（皮下脂肪） $1 \mathrm{~g}$ 及び内部標準品 $\left({ }^{13} \mathrm{C}-2,3,7,8\right.$ TCDF) $0.1 \mathrm{ng}$ を分液漏斗に採り，アセトンーヘキサン $(2: 1, \mathrm{v} / \mathrm{v}) 180 \mathrm{ml}$ で抽出した. さらに 2 回アセトンー ヘキサン $30 \mathrm{ml}$ で抽出し, 抽出液は合した. 蒸留水 30 
Table 3. The PCBs and PCQs Concentration in the Blood and Adipose Tissue Divided into Three Groups with High, Intermediate and Low Levels of PCQs

\begin{tabular}{lcccccc}
\hline \hline & \multirow{2}{*}{$\begin{array}{c}\text { No. of } \\
\text { PCQ Level }(\mathrm{ppb})\end{array}$} & \multicolumn{2}{c}{ Blood $(\mathrm{ppb})$} & & \multicolumn{2}{c}{ Adipose tissue $(\mathrm{ppb})$} \\
\cline { 3 - 6 } \cline { 5 - 7 } & subjects & PCBs & PCQs & & PCBs & PCQs \\
\hline High & 7 & $9.65 \pm 6.34$ & $6.970 \pm 3.380$ & & $2,150 \pm 1,660$ & $1,060 \pm 469$ \\
>1.0 & & $(2.03 \sim 20.60)$ & $(3.86 \sim 13.89)$ & & $(1,000 \sim 5,710)$ & $(555 \sim 1,997)$ \\
Intermediate & 5 & $3.49 \pm 1.82$ & $0.205 \pm 0.247$ & & $1,012 \pm 394$ & $44.9 \pm 45.9$ \\
$0.044 \sim 1.000$ & & $(2.00 \sim 5.95)$ & $(0.047 \sim 0.638)$ & & $(472 \sim 1,460)$ & $(11.2 \sim 120.3)$ \\
Low & 37 & $3.81 \pm 2.50$ & $0.017 \pm 0.012$ & & $907 \pm 428$ & $3.98 \pm 3.97$ \\
$0.000 \sim 0.044$ & & $(1.00 \sim 12.00)$ & $(0.001 \sim 0.041)$ & & $(178 \sim 2,217)$ & $(0.52 \sim 8.22)$ \\
\hline
\end{tabular}

( ): $\min \sim \max$

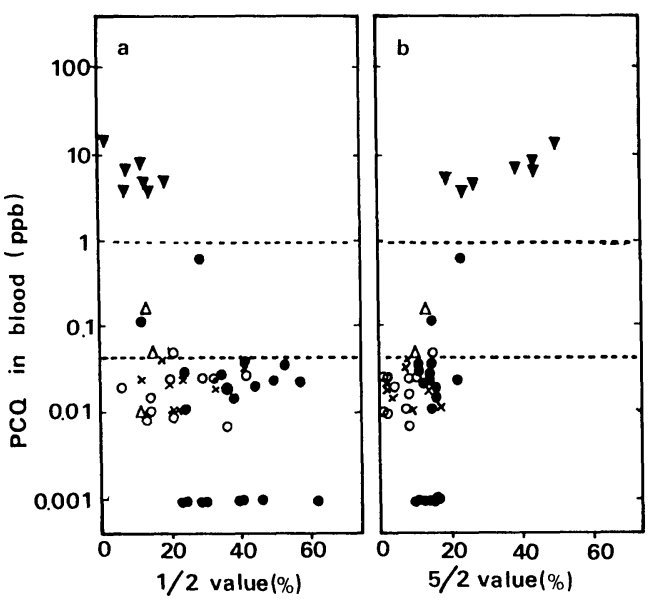

Fig. 1. The correlation between PCQ concentration and $\mathrm{PCB}$ gas chromatogram pattern (a: $1 / 2$ value, the first to second $\mathrm{PCB}$ peak heights ratio; b: $5 / 2$ value, the fifth to second peak heights ratio) of 49 blood samples

Yusho patients ( $\nabla$ : Type A; $\triangle$ : Type BC; $\times$ : Type C)

Normal persons: $\bigcirc$

Patients with other dermal desease:

$\mathrm{ml}$ を加えてへキサン層を分離し，水層は捨てた. 抽出液 は, 蒸留水 $30 \mathrm{ml}$ で 2 回洗浄後, 濃硫酸 $10 \mathrm{ml}$ を加え振 とうし，硫酸が着色しなくなるまで繰り返して，脱脂を 行った. 蒸留水 $30 \mathrm{ml}$ で 3 回洗浄し無水硫酸ナトリウム $10 \mathrm{~g}$ で脱水後, ロータリーエバポレーターで濃縮した。 この試料を活性炭・グラスファイバー混合カラム（7 $\mathrm{mm}$ i. d. $\times 2 \mathrm{~cm}$, 活性炭として $5 \mathrm{mg}$ ）にのせ, まずジク ロロメタンーヘキサン $(1: 9, \mathrm{v} / \mathrm{v}) 20 \mathrm{ml}$ で非コプラナ - PCBs 及び $p, p^{\prime}-\mathrm{DDE}$ (第 1 画分) を溶出させた後, ト ルェン $100 \mathrm{ml}$ でコプラナーPCBs及び PCDFs（第 2 画分）を溶出させた. 第 2 画分のトルエン $100 \mathrm{ml}$ を乾 固させないよう注意しながら $0.5 \mathrm{ml}$ 以下に濃縮し，フ
ロリジルカラム $(6 \mathrm{~mm}$ i. d. $\times 15 \mathrm{~cm})$ にのせた. ジクロ ロメタンーヘキサン $(1: 99, \mathrm{v} / \mathrm{v}) 25 \mathrm{ml}$ でコプラナー PCBs を溶出させた後, ジクロロメタン $50 \mathrm{ml}$ PCDFs を溶出させた. PCDFs 画分は溶媒を室温下ロー タリーエバポレーターで留去後, 精製 $n$-デカンに再溶解 し, GC/MS 分析に供した. GC/MS 测定は Table 1 の 条件で行った。

\section{結果と考察}

1.PCQ 濃度による分類と PCB パターンとの関係

今回の分析結果を Table 2 に示す. 一方, 著者らは別 報7)に示したとおり, 正常人の血中 PCQ 濃度が, 最高值 $0.044 \mathrm{ppb}$, 最低值 $0.000 \mathrm{ppb}$ の範囲にあることを確認 している. また今回調査した A タイプの血液で最低 $\mathrm{PCQ}$ 濃度が $3.86 \mathrm{ppb}$ であった。 そこで $0.044 \mathrm{ppb}$ を第 1 境界値, $3.86 \mathrm{ppb}$ に近くかつ低い值の $1.000 \mathrm{ppb}$ を第 2 境界值とし, Table 2 に示した全被検者を Table 3 に 示すように血中濃度 PCQ 濃度が $0.044 \mathrm{ppb}$ 以下（Low: $\mathrm{L}$ と略す). $0.044 \sim 1.000 \mathrm{ppb}$ (Intermediate: I と略 す.) $1.000 \mathrm{ppb}$ 以上 (High: $\mathrm{H}$ と略す) の 3 グループに 分けた. その結果, $\mathrm{H}$ グループの 7 名は当然の結果なが らすべて典型的油症患者 (A タイプ) であった. I グルー プの 5 名は, 油症患者 2 名, 非油症患者 2 名及び健常者 1 名であり, これらの血中 PCB のガスクロマトグラム パターンは 5 例とも BC タイプであった. L グループの 37 名は, 油症患者 9 名 (BC タイプ 1 名, C タイプ 8 名), 健常者 10 名 (C タイプ) 及び非油症患者 18 名 (C タイプ）であった，血中，皮下脂肪中 PCB 濃度は，平均 值でそれぞれ H グループが, $9.65 \mathrm{ppb}, 2,150 \mathrm{ppb}$, I グ ループが $3.49 \mathrm{ppb}, 1,012 \mathrm{ppb}$ Ｌグループが $3.81 \mathrm{ppb}$, $907 \mathrm{ppb}$ であった.

従って H グループと I, L 両グループ間には PCB 濃度 で 2〜3 倍の差があった. 一方, 血中, 皮下脂肪中 PCQ

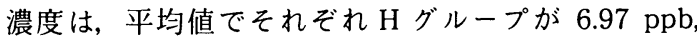
$1,060 \mathrm{ppb}$, I グループが, $0.205 \mathrm{ppb}, 44.9 \mathrm{ppb}, \mathrm{L}$ グル 一プが $0.017 \mathrm{ppb}, 3.98 \mathrm{ppb}$ と段階的に減少し，H グル 一プと L グループ間では, 血液で 410 倍, 皮下脂肪で 266 倍の大きな差が認められた。一方，Fig. 1 は血中 
Table 4. The Concentration of PCBs, PCQs, and PCDFs in the Blood and Adipose Tissue of Five Cases (BC Type) Belonging to the Intermediate Group of PCQ

\begin{tabular}{|c|c|c|c|c|c|c|c|}
\hline \multirow{2}{*}{$\begin{array}{l}\text { Subject No. } \\
\text { (Symptoms as Yusho) }\end{array}$} & \multicolumn{2}{|c|}{ Blood (ppb) } & \multicolumn{5}{|c|}{ Adipose tissue (ppb) } \\
\hline & $\mathrm{PCB}$ & $\mathrm{PCQ}$ & $\mathrm{PCB}$ & PCQ & $\mathrm{T}_{4} \mathrm{CDF}$ & $\mathrm{P}_{5} \mathrm{CDF}$ & $\mathrm{H}_{6} \mathrm{CDF}$ \\
\hline 1 Patient with D. (None) & 2.00 & 0.638 & 472 & 120.3 & 0.000 & 0.237 & 0.013 \\
\hline 2 Yusho patient & 2.03 & 0.163 & 1,270 & 56.7 & 0.000 & 0.142 & 0.000 \\
\hline 3 Patient with D. (None) & 2.00 & 0.119 & 609 & 21.0 & na & na & na \\
\hline 4 Normal person (None) & 5.95 & 0.051 & 1,250 & 15.2 & 0.000 & 0.000 & 0.000 \\
\hline 5 Yusho patient & 5.48 & 0.041 & 1,460 & 11.2 & 0.004 & 0.055 & 0.004 \\
\hline $\begin{array}{l}\text { Average of } 11 \text { normal persons } \\
\text { (S. D.) }\end{array}$ & $\begin{array}{c}3.84 \\
(1.32)\end{array}$ & $\begin{array}{c}0.021 \\
(0.012)\end{array}$ & $\begin{array}{c}893 \\
(262)\end{array}$ & $\begin{array}{r}4.15 \\
(3.82)\end{array}$ & $\begin{array}{c}0.002 \\
(0.005)\end{array}$ & $\begin{array}{c}0.011 \\
(0.013)\end{array}$ & $\begin{array}{c}0.000 \\
(0.000)\end{array}$ \\
\hline
\end{tabular}

D.: means "other dermal desease".

na: means "not analyzed".

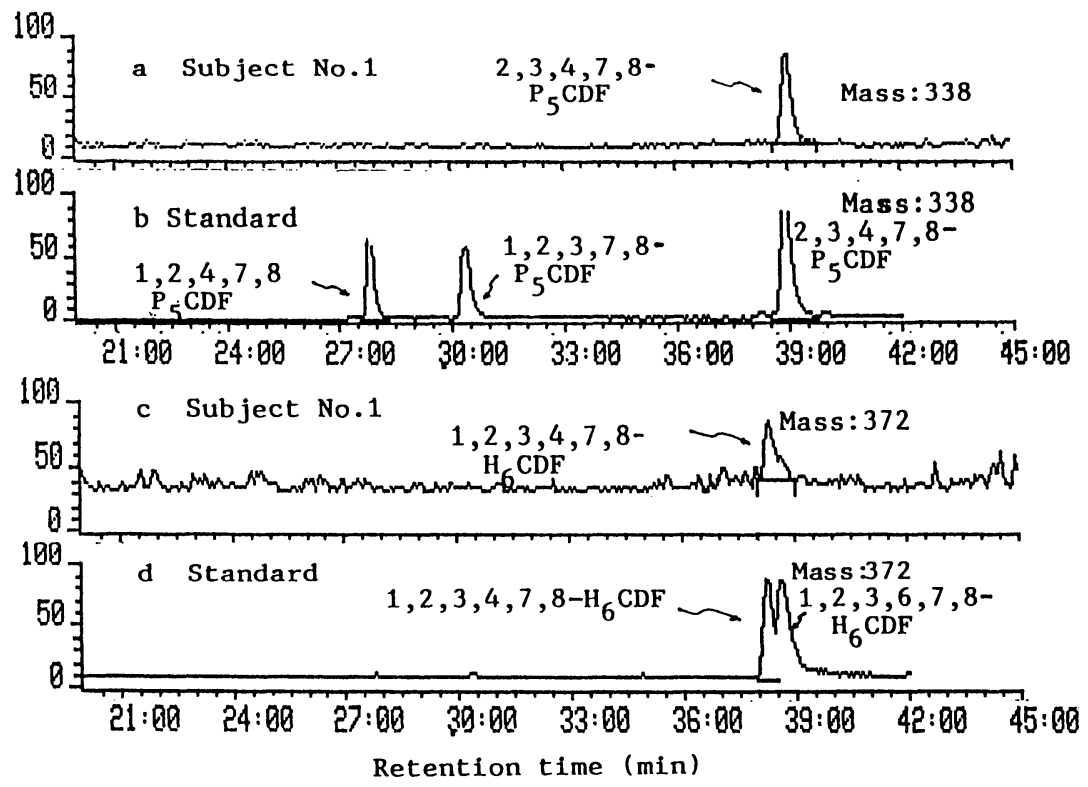

Fig. 2. Mass fragmentograms of $\mathrm{P}_{5} \mathrm{CDFs}$ and $\mathrm{H}_{6} \mathrm{CDFs}$ found in the adipose tissue of subject No. $1(\mathrm{a}, \mathrm{c})$ and standard samples $(\mathrm{b}, \mathrm{d})$

PCQ 濃度と， PCB パターンを決定するガスクロマトグ ラムの $1 / 2$ 值 $\left(p, p^{\prime}-\mathrm{DDE}\right.$ から数えて 2 番目のピーク高 に対する 1 番目のピーク高の比) 及び $5 / 2$ 值 ( $p, p^{\prime}-\mathrm{DDE}$ から数えて 2 番目のピーク高に対する 5 番目のピーク 高の比）との関係を示したものである. 相関係数は各々 0.8 と 0.9 であり, 特に $5 / 2$ 值とは危険率 $1 \%$ 以下 $(p<$ 0.01) での有意な相関を示した. 以上の結果から PCQ 濃 度による分類はPCB パターンの場合と同様の意味をも

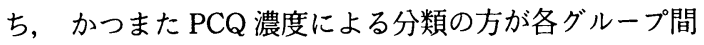
の差も明瞭になることが分かった。これは油症原因油に $\mathrm{PCB}$ と同様に特徵的に多く含有される ${ }^{8} \mathrm{PCQ}$ が，おそら く $\mathrm{PCB}$ 以上に人体からの排泄が緩慢な脂溶性化合物で あることに起因していると考えられる。
2. $\mathrm{PCQ}$ 及び PCDF 濃度からみた $\mathrm{BC}$ タイプの症例 についての考察

BC タイプは現在顕著な油症特有の臨床症状が認めら れにくく的確な油症診断が困難なタイプである. 前述の 結果からこのタイプはおおむね PCQ 濃度による分類の I グループに属することが分かった。 ここではこのグル ープに属する 5 症例 (BC タイプ) について, 詳しく考察 する. 5 症例の血液及び皮下脂肪中 PCB, PCQ 濃度並び に皮下脂肪中 PCDF 濃度を Table 4 に示した。 症例 1 は油症患者ではなかったにもかかわらず, 他の 4 例より 高い血中, 皮下脂肪中 PCQ 濃度, $0.638 \mathrm{ppb}, 120.3 \mathrm{ppb}$ を示し, また, Fig. 2 のマスフラグメントグラムで明ら かなように皮下脂肪中に $2,3,4,7,8-\mathrm{P}_{5} \mathrm{CDF}$ 及び 
1,2,3,4,7,8- $\mathrm{H}_{6} \mathrm{CDF}$ を検出し, その濃度は各々 $0.237 \mathrm{ppb}$ 及び $0.013 \mathrm{ppb}$ であった。これら皮下脂肪中 PCQs, PCDFs 濃度は健常人の平均值の各々およそ 30 倍と 20 倍であった. 問診調査の結果, 既往歷にも目立つものが なく，ただ生活歴として本人の記憶によれば， 16〜19 年程前頃にカネミ食用油を一升瓶で数回購入して使用し たことがあり，同居家族とともに撕取したと言う. 当時, 油症事件の発生を知っていたが，油症と思われるような 自覚及び他覚症状は家族及び本人にも生じなかったの で，保健所にも届出ず，また油症検診も受診せずそのま ま現在に至っていると述べている. 従って, 症例 1 の高 い PCQ 值は, 他に特定される客観的な PCQ の摄取機会 が全く認められないことから, 油症原因油の掑取にのみ 起因することは間違いないものと考えられる. 次に症例 2 と 5 は油症認定患者であり, PCDFs も $0.142 \mathrm{ppb}$ (2,3,4,7,8- $\left.\mathrm{P}_{5} \mathrm{CDF}\right), 0.063 \mathrm{ppb}\left(2,3,4,7,8-\mathrm{P}_{5} \mathrm{CDF}\right.$ は 0.055 $\mathrm{ppb}$ ) と検出された。 これに対し, 症例 3 と 4 は油症と は無関係の非油症患者及び健常者であり, 症例 4 の健常 者の皮下脂肪からは PCDFs は検出されなかった. 1976 年 Nagayama は PCDFs が原因油中に低濃度ながら存 在することを明らかにしだ?. また，PCDFsの毒性に関 しては, Yoshihara らが, PCDFs の一同族体である 2,3,4,7,8-P $\mathrm{P}_{5} \mathrm{CDF}$ が動物実験において強い急性毒性を有 することを(10)，また Kuroki らがその高い肝残留性を報 告している ${ }^{11)}$. 従って現在では $2,3,4,7,8-\mathrm{P}_{5} \mathrm{CDF}$ が油症 の原因物質の中で重要であるとされている。 そこで, 2,3,4,7,8-P $\mathrm{P}_{5} \mathrm{CDF}$ を伴う PCQ の体内残留は原因油摂取を 証明するものであると考えられ, 従って, Table 4 に示 された Iグループ（BC タイプ）は原因油を明らかに撕取 した人とそうでない人が混在するグループであることが 強く示唆される.さらに, 油症を発症しなかった症例 1 (Table 4) の PCQ, PCDF 体内残留に関する知見は, 今後 の油症診断や油症原因物質の毒性研究に大きく影響を及 ぼすのではないかと考えられる。 そして今後も, 潜在的 な油症原因油污染の実態を明らかにするために油症検診 などの調査を継続することが必要と思われる.

結 語

（1）油症患者 18 名を含む 49 名をその血中 PCQ 濃 度により，H グループ(>1.000 ppb)，I グループ (0.044
〜 $1.000 \mathrm{ppb})$ 及び L グループ (<0.044 ppb) に分類し た。をの結果，おおむね， A タイプは H グループに，C タイプは L グループに， BC タイプはIグループに各々 分類された。

（2）血中 PCQ 濃度は，血中 PCB のガスクロマトグ ラムから得られる $1 / 2$ 值 ( $p, p^{\prime}-\mathrm{DDE}$ 力ら数えて, 2 番目 のピーク高に対する 1 番目のピーク高の比）よりも $5 / 2$ 值 ( $p, p^{\prime}-\mathrm{DDE}$ から数えて, 2 番目のピーク高に対する 5 番目のピーク高の比）とにおいて危険率 1\%以下で高い 相関を示した.

（3） BC タイプの症例の中に，油症患者でないのに かかわらず, 皮下脂肪中汇健常人に比べ, 30 倍の $\mathrm{PCQ}$ 及び 20 倍の PCDF を有するものがあった。ここれは問診 調査により油症原因油の摂取によることが分かった。

（4）Iグループ (BC タイプ) は油症原因油を明らか に摄取した人とそうでない人の混在するグループである ことが強く示唆された。

\section{文献}

1）増田義人, 香川梨絵, 島村京子, 高田真由美, 倉恒匡徳: 福岡医誌. 65, 25 27 (1974).

2）片岡恭一郎, 大久保影人, 篠原志郎, 高橋克巳, 增田義人: 同上 74, 296 301 (1983).

3）竹中重幸, 飯田隆雄, 中川礼子, 深町和美, 森 彬, 高橋 克巳，旭 正一: 同上 78,314 319 (1987).

4）中川礼子, 飯田隆雄, 竹中重幸, 深町和美, 森涁, 高橋 克巳, 旭 正一: 同上 78, 309 313 (1987).

5) Ryan, J. J., Lizotte R., Lau, B. P.Y.: Chemosphere 14, 697 706 (1985).

6) Kuroki, H., Masuda, Y.: ibid. 10, 771 777 (1978).

7）飯田隆雄, 竹中重幸, 中川礼子, 深町和美, 森 彬, 高橋 克巳, 旭 正一：福岡医誌. 78, 305 308 (1987).

8) Miyata, H., Kashimoto, T., Kunita, N.: J. Food Hyg. Soc. Japan 19, 364 371 (1978).

9) Nagayama, J., Kuratsune, M., Masuda, Y.: Bull. Environ. Contam. Toxicol. 15, 9 13 (1976).

10) Yoshihara, S., Nagata, K., Yoshimura, H., Kuroki, H., Masuda, Y.: Toxicol. Appl. Pharmacol. 59, 580 588 (1981).

11) Kuroki, H., Masuda, Y., Yoshihara, S., Yoshimura, H.: Food Cosmet. Toxicol. 18, 387 392 (1980). 